Portland State University

PDXScholar

$5-13-1968$

\title{
Assessment of Subjective Experiences of Boys Entering the Community From a Correctional School
}

Thomas W. DeJardin

Portland State University

Theresa F. Eubanks

Mary F. Hoyt

Steven J. Ickes

Carol W. Lane

See next page for additional authors

Follow this and additional works at: https://pdxscholar.library.pdx.edu/open_access_etds

Part of the Social Work Commons, and the Sociology Commons Let us know how access to this document benefits you.

\section{Recommended Citation}

DeJardin, Thomas W.; Eubanks, Theresa F.; Hoyt, Mary F.; Ickes, Steven J.; Lane, Carol W.; and Staat, David F., "Assessment of Subjective Experiences of Boys Entering the Community From a Correctional School" (1968). Dissertations and Theses. Paper 486.

https://doi.org/10.15760/etd.486

This Thesis is brought to you for free and open access. It has been accepted for inclusion in Dissertations and Theses by an authorized administrator of PDXScholar. Please contact us if we can make this document more accessible: pdxscholar@pdx.edu. 


\section{Author}

Thomas W. DeJardin, Theresa F. Eubanks, Mary F. Hoyt, Steven J. Ickes, Carol W. Lane, and David F. Staat 
$\frac{\text { THOMAS W. DeJARDIN et al. for the } \frac{\text { MASTER }}{\text { (Degree) }} \text { in SOCIAL WORK }}{\text { (Mame) }}$ presented on May 3, 1968

Title: ASSESSMENT OF SUBJECTIVE EXPERIENCES OF BOYS ENTERING THE COMMUNITY FROM A CORRECTIONAL SCHOOL

Abstract approved:

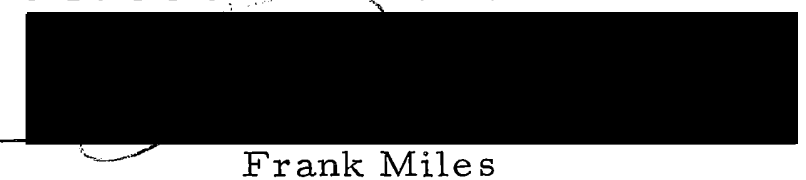

Frank Miles

The purpose of this study was to explore, classify, and evaluate the personal experiences of juvenile offenders following release from a state training school.

During a two month period beginning in the fall of 1967, a group of twenty-three releasees from the MacLaren School for Boys in Woodburn, Oregon were interviewed on a weekly basis in the Portland metropolitan area. The boys, ranging in age from thirteen to seventeen were contacted in their homes, schools, and other settings to learn of positive, negative, and critical experiences encountered in the community.

Open ended questions based upon a twenty-seven item schedule were administered to the boys, focusing upon personal experiences in six major areas: school, family, peer group, community, work 
and authority. Responses were recorded verbatim and classified according to the boys' judgments of positive and negative connotations. Critical experiences were also recorded to determine specific incidents which brought the boys into contact with legal authorities or otherwise seriously affected their parole status.

Positive, negative, and critical experiences from this study were analyzed both descriptively and statistically. Null hypotheses were tested to determine the quality, quantity, and intensity of experiences with respect to such major variables as age of the boys, race, length of stay in the community, records of school attendance, and personality inventory characteristics. Experiences were similarly related with respect to other variables found to be present as a result of the interviewing experience.

Findings yielded evidence to indicate a predominance of negative experiences in the boys' contacts with the community following release. The highest proportion of these occurred within the boys' families, followed by contacts with authority and school, respectively. Peer group relationships for the boys indicated the highest proportion of positive experiences when compared with other major categories. 


\section{ASSESSMENT OF SUBJECTIVE EXPERIENCES OF BOYS ENTERING THE COMMUNITY FROM A CORRECTIONAL SCHOOL}

by

$\begin{array}{ll}\text { Thomas W. DeJardin } & \text { Steven J. Ickes } \\ \text { Theresa F. Eubanks } & \text { Carol W. Lane } \\ \text { Mary F. Hoyt } & \text { David F. Staat }\end{array}$

A GROUP PROJECT

submitted to

PORTLAND STATE COLLEGE

in partial fulfillment of

the requirements for the

degree of

MASTER OF SOCIAL WORK

June 1968 
APPROVED:
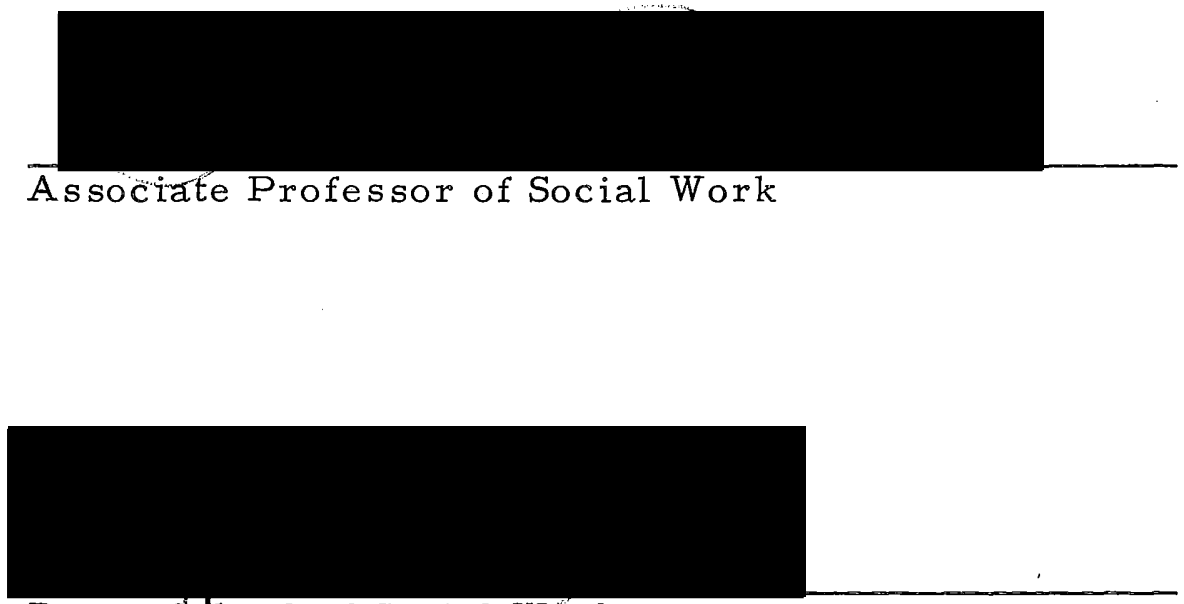

Dean, Shhool of SocialWWork

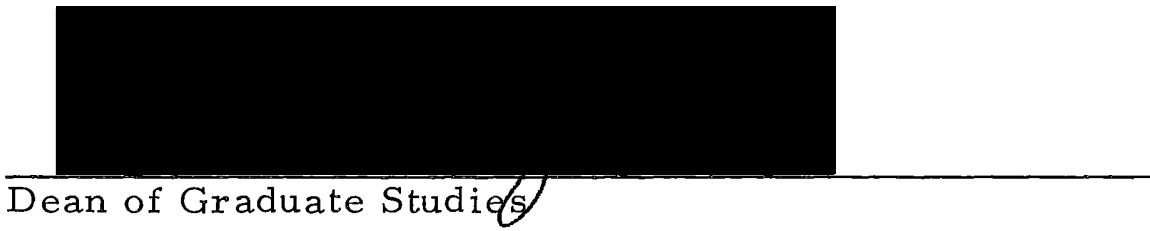

Date group project is presented

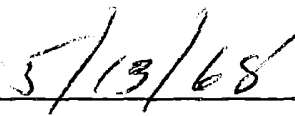

Typed by Illa W. Atwood 


\section{ACKNOW LEDGMENTS}

The research group wishes to express its appreciation to the members of the social work community who gave of their time and counsel to assist in bringing this project to fruition, and to the boys from MacLaren School who cooperated by providing the research data.

To Mr.Amos Reed, Superintendent of MacLaren School for Boys, Mr. Hinsey, head of Psychological Services at MacLaren, Mr. Ben Talley, Supervisor of MacLaren Parole Officers, and Miss Mary Padovan, Director of Social Services for the Portland Public School System, and Mildred Bennett, Portland State Mathematics Department, go our thanks for their advice and suggestions. In addition, special thanks are acknowledged to Mr. Frank Fair, Director of the C-CAP Opportunity School, and to his boys who helped in the initial phase of the study.

Finally, the research group wishes to express sincere grati-

tude to our research advisor, Dr. Frank Miles, Associate Professor of Social Work, Portland State College. Dr. Miles gave not only constant support and guidance to this project, but also fostered in each of us an excitement and enthusiasm for social research. Our association with Dr. Miles will long be remembered in the future.. 
TABLE OF CONTENTS

Chapter

I. INTRODUCTION

Purpose of the Study 1

Rationale 2

Development of. Focus 4

Definition of Terms 6

$\begin{array}{ll}\text { Hypotheses } & 7\end{array}$

$\begin{array}{ll}\text { General Overview of the Study } & 7\end{array}$

II. REVIEW OF THE LITERATURE

General Theory 9

$\begin{array}{ll}\text { Critique of Theory } & 14\end{array}$

$\begin{array}{ll}\text { Empirical Studies } & 15\end{array}$

$\begin{array}{ll}\text { Conclusions } & 22\end{array}$

III. METHODOLOGY

$\begin{array}{ll}\text { Research Design } & 30\end{array}$

Formulating Interview Questions 32

Results of the Pretest 34

Study Hypotheses $\quad 36$

Selecting the Study Population 37

Collecting Background Data 38

Limits on the Study Population 39 
Conducting the Interviews

Tabulation and Statistical Analysis

IV. FINDINGS

$\begin{array}{ll}\text { Consideration of Major Variables } & 47\end{array}$

Consideration of Internal Variables 51

Consideration of Observed Data Within Each Category

Consideration of Supportive Data

V. CONCLUSIONS

Major Findings and their Implications for Practice

Further Findings

Criticisms and Implications 


\section{LIST OF TABLES}

Table

Page

1. Categories in Which the Number of Positive and Negative Experiences Reported Were Significantly Different

2. Categories in Which the Number of Positive and Negative Experiences Reported Were Not Significantly Different

3. Categories in Which the Number of Positive and Negative Experiences Reported Were Not Significant, Comparing September and October

4. Categories in Which the Number of Positive and Negative Experiences Reported Were Not Significant, Comparing Negro and White Boys for September and October

5. Categories in Which the Number of Positive and Negative Experiences Reported Were Significant and Not Significant, Comparing Older and Younger Boys in the Two Month Period

6. Number of Critical Incidents Reported in September and October

7. Frequency of Reported Scores in the MMPI the Number Four and Six Scales, the Psychopathic Deviate (PD) and Paranoid (PA). 


\section{ASSESSMENT OF SUBJECTIVE EXPERIENCES OF BOYS ENTERING THE COMMUNITY FROM A CORRECTIONAL SCHOOL}

\section{CHAPTER I}

\section{INTRODUCTION}

This is an exploratory study which focuses on the subjective experiences of twenty-three boys released from MacLaren School for Boys in Woodburn, Oregon.

MacLaren, the State of Oregon's training school for delinquent boys, is located 35 miles south of Portland. It is situated in a predominantly rural community. Boys brought to the courts' attention between the ages of 12 and 18, from twenty-six counties in the State, must be court committed to the institution.

The typical length of incarceration for a boy may range from six months to two years, and in some instances longer. Boys may be committed to MacLaren for a variety of reasons ranging from incorrigibility to seriously illegal behavior, car theft, forgery, rape or murder.

Usually, Portland area boys present a lengthy history of contacts with social welfare agencies in the community before commitment to MacLaren.

Upon release from MacLaren, the boys are placed in physical 
custody of their parent or parents, foster parents, or relatives. The majority of the MacLaren releasees reenter the Portland Public School System. They are also under the supervision of a parole officer from MacLaren. The field counselors or parole officers who supervise the boys in the Portland area have their offices in downtown Portland. The frequency of the parole officer's contacts with the boys is dependent upon the individual needs of the boys and increases during times when boys become involved with the law. Another determinant in the frequency of contacts with the boys is the size of the parole officer's caseload.

Specifically, the purpose of this study was to discover and classify varieties of experiences, both positive and negative, relating to post release adjustment of boys reentering the Portland community after incarceration at MacLaren School for Boys.

The study was not treatment focused or therapeutic in nature. An exploratory emphasis was maintained on the subjective experiences of the boys themselves, as they reacted.

\section{$\underline{\text { Rationale }}$}

This study was initiated by a committee of the Portland Public Schools interested in improving the adjustment of boys from MacLaren and in reducing their rate of drop-out from school. The MacLaren School was most interested in cooperating, in part because 
of their experiences in having boys eager for a new life and apparently ready for reentering the community, but who nevertheless failed.

Literature in the area of crime and delinquency reveals that a boy is stigmatized by institutionalization. However, there have been few studies that represent an attempt to ascertain what confronts the boy upon his return to the community, according to his subjective feelings.

In a previous study at the School of Social Work, Portland State College, Allen et al. examined seven areas of attitudes; authority, fear, aspirations for the future, obstacles to be overcome, capabilities, societal ideals and therapy through the use of the in-depth interview (1).

This study uncovered a number of unsuspected problem areas related to community, peer and adult rejection, singling out, and other barriers to readjustment and their concomitants in subjective burdens and overt relationships.

It was therefore reasoned that an important element in readjustment might be the subjective reactions to various circumstances encountered. Also, these subjective experiences might differ from objective interpretations and expectations as determined by the community in which the boy was living. 


\section{Development of Focus}

From the initial undertaking of the project, it was understood by the research group that the weekly interview with the subjects would not involve treatment. This was also stressed in the initial contact with each boy. The matter of confidentiality was discussed with each boy by a member of the research group. Each boy was advised that information given to an interviewer would not be shared with his parole officer, school officials, or any other individuals other then members of the research group conducting the study. The boys in the study population were also advised that the interviewer contacting him would not have any knowledge of the boy's background or reason for his commitment to MacLaren. This decision had been made earlier in the study to prevent bias on the part of the interviewer.

In addition, in the initial interview with each boy, it was explained that participation in the study was voluntary.

To become more attuned to problems facing the youths released from MacLaren, two members of the research group spent a few hours one day a week for five consecutive weeks at the C-CAP Opportunity School. This is a school sponsored by the Community Action Program in the Albina area of Portland. This program is under the direction of the Portland Council of Churches. All boys 
enrolled in this school had dropped out of the local high school program for various reasons and were enrolled in the C-CAP school which provided a much less structured program which was geared to a boy's individual needs and capabilities.

Out of the contact with these youths, a tentative schedule was solidified and pretested. After reviewing the results of the pretest, the schedule was revised to serve as a check list in the weekly interviews with the boys.

In talking with the boys at C-CAP, the research group found that the boys' experiences could be classified under six major areas. These areas of relationship were 1. School, 2. Family, 3. Peer group, 4. Community, 5. Work, and 6. Authority. Each major heading included sub-categories. Under School were the subcategories of teachers, vice principal, principal, counselor, students and other; under Family were father, mother, substitute parents, brother(s), sister(s), and other; under Peer group were close male friends, mixed group, girl friend; the subcategories under Community were welfare caseworker, medical, church, community action, neighbors; the Work category included employer, co-workers, interviews; the category of Authority was comprised of parole officer, police, juvenile court, other.

It should be noted that after several interviews with various boys, the usage of drugs was brought up voluntarily by the boys and 
the category was then arbitrarily included as drugs under the major heading of Community.

\section{Definition of Terms}

For the purpose of this study, it was determined that a critical incident would be defined as "any act or experience of either positive or negative value to the boys which could result in their being returned to MacLaren." The boys designated whether an incident was or was not critical.

A positive experience was determined to be an experience in which the outcome was related to "meeting some social, psychological or emotional need of the boy." A negative experience for a boy was defined as one in which "some social, psychological or emotional need of the boy is not met."

The term subjective was defined by the research group as "each boy's individual perception of an incident or experience." The objective view of an incident was limited to the official records of the police, juvenile court, or MacLaren.

It should also be noted that some of the interviewers learned that many boys found some activities such as taking drugs and drinking beer as being positive experiences even though these acts were violations of Oregon statutes and could result in his return to MacLaren. There seemed to be a frequent variance between what 
the boys viewed as positive and the prescribed norms of society.

\section{Hypotheses}

The aims of the project were approached through the use of null hypotheses. They were stated in null form because as an exploratory study there was as yet no empirical evidence as to direction even though certain relationships had been suggested. The hypotheses were related to significant differences between the major variables that were studied; school, family, peer group, community, work, and authority. The reader may refer to Chapter III, pages 36 and 37 of this study for further detail and clarification.

\section{General Overview}

Beginning with the general problem of boy's readjustment to. the community upon release from a training school, the study focused on subjectively viewed experiences in six areas of relationship. Twenty-three boys were found and contacted at least once a week for eight weeks. These constituted $50 \%$ of the boys released to the Portland area during the spring and summer of 1967 and reentering school for the fall term of 1967.

Analysis was designed to explore major sources of positive and negative experiences, types of experiences and their relationship to adjustment.

The following chapters develop the se elements in greater detail. 


\section{Chapter Notes}

1. Allen, et al., "Use of the Depth Interview in Examining Attitudes of Delinquent Boys: An Exploratory Study, "Portland State College, School of Social Work, Portland, Oregon, 1964. p. 51. 
CHAPTER II

\section{REVIEW OF THE LITERATURE}

This chapter presents a review of literature on delinquency. It focuses on general theories of delinquency, empirical findings of both research and research/action studies, and the concerns of some writers about current methods of processing delinquents.

\section{General Theory}

Critics of research on delinquency have pointed to the ". . . explicit or implicit theories of delinquency . . " (1) that researchers assume, as one of the possible villains in the alleged failure of delinquency research to produce conclusive and consistent results (la). Theories about delinquency have covered a wide range of factors operative upon the child. These factors fall into the three broad categories of environment, psyche, and physiology (organic and constitutional)(2).

Hirschi summarizes Barbara Wooton's study of 21 methodologically similar delinquency studies. He lists the following twelve factors associated with criminality and delinquency:

1. The larger the family, the more likely the child is to become delinquent.

2. Criminality among other members of the family is fairly strongly related to delinquency. 
3. Church attendance is negatively related to delinquency.

4. No good evidence has been collected to suggest that club member ship is related to delinquency, either positively or negatively.

5. Poor workers are more likely than good workers to be delinquent.

6. Delinquency is negatively related to social class.

7. Taken as a whole, these studies suggest a relation between poverty and delinquency.

8. Employment of the mother outside the home is not related to delinquency.

9. There is no relation between health and delinquency.

10. The better the child's performance in school, the less likely he is to become delinquent.

11. Truancy and delinquency are highly related.

12. Children from broken homes are at least slightly more likely than children from intact homes to become delinquent. ( $1 \mathrm{~b}$ )

Recent governmental activity and intervention in the poverty situations of the country has been accompanied by an emphasis in the literature upon the multi-dimensional aspects of delinquency with a special focus on the cultural dimension.

. . the delinquency of any given child is best understood in terms of the full motivational-situational-cultural complex within which it occurs. The best perspective for understanding such complexes is an interdisciplinary theory which first emphasizes the social and cultural roots of behavior, then the psychic. 
Ellington quotes the President's Commission of 1965 in citing

factors which frustrate institutional rehabilitation:

What research is making increasingly clear is that delinquency is not so much an act of individual deviancy as a pattern of behavior produced by a multitude of pervasive societal influences well beyond the reach of the actions of any judge, probation officer, correctional counselor or psychiatrist ...(4)

Criminologists such as Enrico Ferri in Italy and Clifford Shaw in this country have proposed that to change most delinquent and criminal behavior, effort should be directed at factors in the environment (4a). Yet, until this decade, the dominant theories continued to account for antisocial behavior by defects in the individual (4b).

Shaw's view of delinquency is reflected in the "opportunity theory, "proposed by Cloward and Ohlin. It explains the delinquency bred in slums as a result of youngsters' not having real access to the ladders that lead to social betterment. Because of their social, economic, physical and cultural deprivation, they are severely disadvantaged in the race for life's material rewards by the time they reach kindergarten age.

Ohlin and Cloward suggest that such deprivations induce youngsters to turn to forbidden acts to achieve the gratifications that they cannot secure through socially sanctioned means. (5)

Extending this theory necessitates the conclusion that the treatment of this type of delinquent through the clinics, courts and 
institutions can do little to stem the tide of delinquency. Treatment would consist of helping the delinquent develop his own capacities to the point where he could climb out of the social morass (5a).

While the opportunity theory has attempted to explain lower class delinquency, empirical studies have shown that deviance of adolescents exists in some form in all socioeconomic classes. Cohen and Short have stated there is a "poverty of speculation" about middle class delinquent subcultures.

The saddest commentary, however, is that we are faced with a poverty of speculation, without which there can be no meaningful research, without which in turn, there can be no conclusions that are more than speculation.

\section{Elliott suggested:}

Any valid theory of delinquency should cover both lower class and middle class delinquency. The one theory which offers much validity for both groups has been largely ignored, however, namely that the physical, emotional and intellectual problems which adolescence itself entails are related to non-conforming behavior.

Erik Erikson cites some of the problems of adolescence which make the child particularly vulnerable to deviancy.

What the regressing and growing, rebelling and maturing youths are now primarily concerned with is who and what they are in the eyes of a wider circle of significant people as compared with what they themselves have come to feel they are, and how to connect the dreams, idiosyncrasies, roles and skills cultivated earlier with the occupational and sexual prototypes of the day.

Erikson observes that these youths, bewildered by their roles, 
run away, leave school and jobs, stay out at night, or withdraw into bizarre and inaccessible moods. If the adolescent acts out in a delinquent manner:

- . his greatest need and often his only salvation is the refusal on the part of older youths, of advisors, and of judiciary personnel to type him further by pat diagnoses and social judgments which ignore the special dynamic conditions of adolescence. (8a)

Juvenile delinquency as it has come to be defined since 1948 , according to Wattenberg, is regarded as one symptom of a cluster of problems related to the alienation of many adolescents from the culture and its established institutions (9). Wattenberg also viewed with much alarm certain aspects of the adolescent's alienation which do not bear the label of delinquency, and in so doing reflected Erik-.. son's diagnoses of "role diffusion." (8b)

Yet at the same time that the type of social mal-adjustment which takes the threatening form of delinquency captures our attention, we are also aware that among youth who are comparatively well provided for, there is a type of personalistic, uninvolved, and decadent current of values which, while not so dramatic, may in the long run prove even more destructive. To this type of malad justment are applied such terms as "existential crisis" and "identity diffusion." (9)

Ralph England discussed the phenomenon of a "teenage culture" and offered an historical explanation for what Erikson and Wattenberg termed role and identity diffusion. He spoke of the deactivation of this large segment of our population and noted that society has not 
given the adolescent a status or role to compensate for the deactivation.

The groundwork for the emergence of a teenage culture in our society was laid a century and more ago when youngsters were gradually removed from functional roles in the economy through restrictive apprenticeship codes, protective labor legislation, the compulsory education movement, and the withdrawal of children from agricultural activities attendant upon urbanization.

However diverse the forces were which led to this removal from productive roles, the result was that for probably the first time a major society deactivated a large and energetic segment of its population without clearly redefining the status and function of that segment. (10)

\section{Critique of Theory}

If theory becomes general enough to encompass all delinquency, it becomes too general to isolate into testable hypotheses. Ohlin and Cloward's "opportunity theory" which has offered an explanation for lower class delinquency has not accounted for middle clas delinquency. Yet, one theory cannot explain all delinquency since delinquency can be symptomatic of numerous kinds of dysfunctioning.

The empirical findings as well as theory highlight the importance of clarifying the role of variables and the conditions under which specific variables affect delinquency. 


\section{Empirical Studies}

Empirical findings on the rates of officially detected and undetected delinquency of middle class youngsters have been published. Some studies focused on differentiating between delinquents and non-delinquents using personality measures such as the Minnesota Multiphasic Personality Inventory (MMPI), and self concept scales.

Two research/action studies present empirical approaches to delinquency prevention, the Atlantic Street Study (11) and Streetcorner Research (12). Little empirical research was found relating specifically to problems of releasees from training schools (13).

Gold stated that one of the problems in research on delinquency is that it usually begins in the official records of police, courts, and institutions. He cited a study of a Michigan city which showed that boys who lived in poorer parts of town, apprehended by police for delinquency, are four to five times more likely to appear in some official record than boys from wealthier sections who committed the same kinds of offenses, In this study Gold found "a statistically significant inverse relationship between class and delinquency, but the strength of the relationship was extremely slight, a coefficient of $-.12 . "(14)$

Erickson and Empey studied a sample of males, ages 15-17, 
for officially detected and undetected offenses (15). The sample contained 50 official non-delinquent boys (tho se never known to the court or police), 30 one-time offenders, 50 persistent offenders, and 50 incarcerated offenders. The researchers found that official records seemed more accurate in reflecting an individual's single, most serious violation, rather than showing his pattern of offenses, either serious or non serious, most commonly committed. No significant differences were found between the official non-delinquent and the one-time offender as to frequency or seriousness of offense, with one exception. The official one-time offenders were more involved in destruction of property.

Nye, Short and Olson gathered data by interview and questionnaire from 2,350 boys and girls in grades nine through twelve in the high schools of three western cities ranging in size from 10,000 to 25, 000. They also questioned a total of 515 boys and girls from mid western, suburban residential homes. These boys and girls had not been adjudged delinquent in their respective communities.

The sample contained children whose fathers' range of occupations included unskilled and semi-skilled labor (migratory worker to restaurant cook) to professional and large business (e.g., interior decorator to United States Supreme Court Justice).

The authors accepted the null hypothesis that there is no significant difference in undetected delinquent behavior of boys and girls 
in different socioeconomic strata (16).

Ohlin maintains that middle class delinquency is petty in comparison with lower class delinquency (17). Researchers, however, have reported on the frequent and regular theft of expensive items by middle class gangs (17a) and the occurrence of physical aggres siveness and violence in middle class gangs (17b).

Reckless and his associates have studied the correlation of self-concept with insulation against delinquency. They concluded that delinquents have poor self-concepts and non-delinquents have good self-concepts. The studies also suggested that a good selfconcept will insulate against delinquency, Reckless suggested that the behavioral scientist should attempt to change the unfavorable direction of socialization and self-concept in those children who are veering toward delinquency (19).

Numerous studies have been successful in differentiating clinically separable groups of delinquents $(20,21)$ and delinquents and non-delinquents (22) through use of the Minnesota Multiphasic Personality Inventory. Monachesi compared profiles of delinquents. (23). However, the various scales of the MMPI combined to give different profiles of delinquents and non-delinquents in the different studies. 
Critique of Empirical Findings

Many problems arise in the research on delinquency from differences in definition of delinquency and confusion as to alleged causal relationships. If treatment approaches depend on research findings for direction, it is very important that the role of variables is made clear. Only in this way can intervention be effective, Hir schi states:

- . The goal of delinquency research should not be to find the relationship between a variable and delinquency, but to learn how and under what conditions a variable does or does not affect delinquency. (ld)

In commenting upon the confusion in the literature of both research and theory, Tangri and Schwartz point out that it is possible to support findings which indicate (a) more delinquency in the lower class than in the middle class, (b) more delinquency in the middle class than the lower class, or (c) no differences by class (18). Further, while it has been pointed out that delinquents and nondelinquents have different perceptions of the structure which they confront, in no case has it been determined that the se perceptions preceded delinquency or non-delinquency or are a consequence of delinquency or non-delinquency. Tangri and Schwartz level this same criticism at studies which claim to discriminate between delinquents and non-delinquents on the basis of personality measures (18a). 
Empirical Research/Action Studies

Berleman and Steinburn discussed the pretest of the Atlantic Street Study, a research/action community youth project (11).

The subjects, seventh grade boys with high delinquency potential, were randomly selected and assigned to experimental and control groups. Data regarding school grades, citizenship patterns, school attendance, home composition and health records were used to select the population.

The subjects were given intensive service for a period of five months from February, 1964 through June, 1964. The least time any boy was in direct contact with his worker was forty-five and one-half hours; the most, one hundred hours. A boy and significant others received the median amount of seventy-five hours' service. In addition to the collection of offense information on the subjects, school and police data were gathered on the control group, the service attrition group, i. $e_{\text {, }}$ tho se boys selected for service but who refused to participate and the low-risk group, i.e., those boys not designated as high risk in the selection process.

The experimental group, with service, performed better than the control group. With termination of service, however, the experimental group reverted back to the same relative level of performance which it had prior to the service. 
Berleman and Steinburn cited this pretest as an implementation of rigorous procedural and evaluative techniques. They supported the need for more exact evaluations of intervening variables in social experiments; they also suggested that with more complete data on the actual amount of service given, evaluation of services and theories underlying services will be more accurate.

Berleman and Steinburn cited other studies which have used the comparison of an experimental or treated group with a control or untreated group in assessing the effectiveness of a delinquency prevention service (11).

Allen, et al. explored through limited depth interview the attitudinal areas of authority, fear, aspirations for the future, obstacles to be overcome, capabilities, societal ideals and therapy of fifteen male subjects. Five of the subjects were institutionalized at MacLaren, five were parolees from MacLaren, and five were probationers at the Juvenile Court. The boys were interviewed to determine their ideas as to what constituted good therapy for them. The observers noted that over eighty-five percent of the time the boys indicated "having some person listen to him talk" and "having some person talk to him" was most helpful (2a).

Schwitzgebel described a research action program in the Cambridge-Boston-Lynn area of Massachusetts which utilized "listening to," "tálking to," and "engaging in activities with" 
twenty-five delinquent boys. These boys ranged in age from fifteen to twenty-one. Twenty of the boys were serious offenders with extensive court records, who had spent at least six months or more in reform school or prison. All of the boys were known to probation officers and social workers.

Each boy was employed as an experimental subject and was paid for the time he spent talking into tape recorders in the researcher's presence. The researchers also helped the boys in activities such as fixing electronic equipment and learning to drive cars (12). The "talking" evolved into a treatment which consisted of the boys' gaining insight about their problems. The researchers suggested that the opportunity to talk, the payment of wages, and the activities with the boys generally resulted in some changes of their philosophies of life (12a). They found there were significantly fewer arrests for the experimental group (three years after their employment in the project) when compared to a matched-pair control group. However, the percentage of experimental subjects incarcerated was not significantly less than the control group in the three year followup period. Neither did they find that the number of months of incarceration of the experimental group differed significantly from the control group (12b). 


\section{Conclusions}

In addition to the attention to theory and empirical findings in the literature, numerous writers have conveyed concern about the treatment of children after they have been adjudged and labelled delinquent.

Perhaps a child adjudged delinquent can expect to elicit from those around him reactions different from tho se he would have elicited had he not been adjudged and labelled delinquent. The reactions of adults and peers in the child's environment after his arrest, adjudication, or official action may produce differences between delinquents and non-delinquents that were not present prior to the official action (1d).

In discussing the negative impacts of processing juveniles who commit non-criminal acts through a correctional system, William Sheridan stated:

There is a considerable body of opinion which holds that the label of "delinquent" sets a young ster apart from his peers--in his own estimation and by the community in general. Through forced association with others similarly labelled, this feeling is re-enforced. He begins to think of himself as a delinquent and acts accordingly. (24)

Many youths, as Edwin Lemert discussed, live with a preponderance of variables linked to delinquency, i.e., poor housing, broken homes. A juvenile court record in the form of wardship, 
placement, or commitment to a correctional institution, is the imposition of a stigma. This stigma brings upon them heightened police surveillance, neighborhood isolation, lower receptivity and tolerance by school officials, and rejection by prospective employers. As a result of the stigma and society's reaction to it,

They [social rejections] may feed a brooding sense of injustice which finds expression in further delinquency, or they may support, strengthen and perpetuate ideological aspects of delinquent subcultures. In this sense the juvenile court may become a connecting or intervening link of a vicious circle in which delinquency causes delinquency (25).

School is one of the avenues by which adolescents approach finding an occupational niche in the community. School is a difficult adjustment for delinquents. In a 1959 workshop some of the staff at the Hawthorne Cedar Knolls School explained the meaning of school from a delinquent's point of view.

The delinquent boy or girl sees school very sharply as a place of failure, frustration, and irritation . . Of all the things which they regard with the greatest suspicion, school is foremost in the picture. . . school is the place where he sees conformity in its full call, authority and adult control in full view, and exposure before one's peers as immediate and catastrophic. School is, in most cases, the place of first failure, the first symptom of an open break with the adult world. (26)

Society's attitude is relatively unbending about the kind of education our children should have. Sidney Marland has stated:

The popular attitude toward occupational, vocational, and technical education, among pupils, parents, teachers, 
and even counselors, reflects an intellectual snobbery that has critically curtailed the overdue revival of this arm of public education. (27)

A review of the literature suggests numerous guides for fur ther research in the field of delinquency. There is a need for more precise definition of delinquency, including a differentiation of types of delinquency. Relationships among variables should not be as sumed to represent causal relationships. Researchers, and those who treat delinquents, should be aware of the labeling and processing practices of society, insofar as they may become variables in themselves by causing stigmatization of youngsters.

Allen, et al., made the following observation:

The delinquent's concept of an ideal society was explored in order to learn how he perceives society. All the interviewees were scored remarkably high in the area of changing other people and redistributing power in order to create an ideal society. (2b)

The delinquent's proposed remedy bears much similarity to the remedy proposed by the President's Commission of 1965. Ellington, in discussing the need for preventive and treatment programs based on causative factors, quotes the Commission:

Until recently, reformers have tended to ignore the evidence that crime and delinquency are symptoms of the disorganization of the community as well as individual personalities and that community institutions--through extending or denying their resources-have a critical influence in determining the success or failure of an individual offender. (4c) 
This chapter has presented a review of literature on delinquency. The grouping of all the acting out of youngsters under the heading of "delinquency" has presented many problems both in empirical research and theory formulation. Differentiation is essential if theory and empirical findings are to become usable for determining prevention and treatment. The officially undetected delinquency of a middle class child has different implications than the delinquency of a parolee. Further the processing of a delinquent may become a variable with ongoing effects upon the child.

This study has been concerned with boys who had been adjudged delinquent and institutionalized. It has continued in a similar vein of investigation used by Allen, et al., that is, approaching the "delinquent" for his perceptions. This study has sought his evaluation of his experiences in various aspects of community life. It represents an attempt to isolate the factors that perpetuate failure or contribute to the success of a parolee. 
Chapter Notes

1. Hirschi, Travis and Hanon Selvin, Delinquency Research: An Appraisal of Analytic Methods, New York, The Free Press, 1967, p. 16.

la. Ibid., p. 16 .

lb. Ibid., p. 57.

lc. Ibid., p. 25.

1d. Ibid., p. 30 .

2. Environmental, psychic, and physiological theories of delinquency are discussed in Allen, Alice, et al., "Use of the Depth Interview in Examining Attitudes of Delinquent Boys: An Exploratory Study, " (unpublished group thesis, School of Social Work, Portland State College, 1964), pp. 20-43.

2a. Ibid., p. 102 .

2b. Ibid., p. 100 .

3. Martin, John M.: "The 'Sociological Imagination' Applied to Juvenile Court Policy-Making, "American Journal of Orthopsychiatry, Vol. 37 , No. 2, 1967, p. 363.

4. Ellington, John R., "Youth Authority Plan and Its Development in California, "California Youth Authority Quarterly, Vol. 20, No. 3, Fall, 1967, p. 29, quoting the President's Commission.

4a. Ibid., p. 20.

4b. Ibid., p. 20 .

4c. Ibid., p. 20 .

5. Beck, Betram M., "Innovations in Combating Juvenile Delinquency," Children, Vol. 12, No. 2, March-April, 1965, p. 70.

5a. Ibid., p. 70 . 
6. Cohen, Albert and James Short,. "Research in Delinquent Sub-Cultures, " Journal of Social Issues, Vol. 14, No. 3, 1958, p. 34, as cited by Myerhoff, Howard and Myerhoff, Barbara. "Field Observations of Middle Class 'Gangs'," Social Forces, vol. 42, No. 3, March 1964, p. 330.

7. Elliot, Mabel, $\mathrm{Ph}$. $\mathrm{P}$. , "Trends in Theories Regarding Juvenile Delinquency ard Their Implications for Treatment Programs," Federal Probation, Vol. 31, No. 3, September, 1967, p. 7.

8. Erikson, Erik, Childhood and Society, New York, W. W. Norton and Company, 1950, p. 266.

8a. Ibid., p. 267.

8b. Ibid. , p. 227 .

9. Wattenberg, William W., Social Deviancy, Chicago, National Society for the Study of Education, 1966, pp. 1-3.

10. England, Ralph, Jr., "A Theory of Middle Class Juvenile Delinquency, "Journal of Criminal Law, Criminology, and Police Science, Vol.50, No. 6, March-April, 1960, p. 536.

11. Berleman, William and Thomas Steinburn,. "The Execution and Evolution of a Delinquency Prevention Program, "Social Problems, Vol. 14, No. 4, 1967, pp. 413-423.

12. Schwitzgebe1, Ralph, Streetcorner Research, Cambridge, Massachusetts, Harvard University Press, 1964.

12a. Ibid., p. 37.

12b. Ibid., pp. 140-141.

13. The relationship between degree of anxiety and parole success was examined by Holleman, James, John McCune and Ray Thomas in "Manifest Anxiety and the Post-Institutional Adjustment of Young Offenders, "Journal of Research in Crime and Delinquency, Vol. 3, No. 1, 1966, pp. 53-56.

14. Gold, Martin, "Undetected Delinquent Behavior," Journal of Research in Crime and Delinquency, Vol. 3 No. 1, January, 1966, p. 27-46. 
15. Erickson, Maynard and Lamar Empey, "Court Records, Undetected Delinquency and Decision Making, " Journal of Criminal Law, Criminology, and Police Science, Vol. 54, No. 4, December, 1963, pp. 456-469.

16. Nye, F. Ivon, James F. Short and Virgil J. Olson, "Socioeconomic Status and Delinquent Behavior, "The American Journal of Sociology, Vol. 63, No. 4, January 1958, p. 381389.

17. Empey, Lamar L., "Delinquency Theory and Recent Research," Journal of Research in Crime and Delinquency, Vol. 4, No. 1, January 1967, p. 31, cites Ohlin, Lloyd. The Development of Opportunities for Youth, New York, Syracuse University, 1960, pp. 8-9.

17a. Ibid., p. 31, citing Myerhoff, op. cit., pp. 328-336

17b. Ibid., p. 31, citing Karacki, Larry, and Jackson Toby, "The Uncommitted Adolescent. Candidates for Gang Socialization," Sociological Inquiry, Spring 1962, pp. 303-315.

18. Tangri, Sandra S., Michael Schwartz, "Delinquency Research and the Self-Concept Variable, " Journal of Criminal Law, Criminology, and Police Science, Vol. 58, No. 2, 1967, pp. 182, citing Westie and Turk, "A Strategy for Research on Social Class and Delinquency, "Journal of Criminal Law: Criminology, and Police Science, Vol. 56, 1965, pp. 454-462.

18a. Ibid., p. 182 .

19. Reckless, Walter C., Simon Dinitz and Ellen Murray, "Self Concept as an Insulator against Delinquency, "American Sociological Review, Vol. 21, No. 6, December 1956, pp. 744-746.

20. Rowley, Vinton and Beth F. Stone, "MMPI Differences between Emotionally Disturbed and Delinquent Adolescents, " Journal of Clinical Psychology, Vol. 18, No. 4, 1962, pp. $481-484$.

21. Shinohara, Atsuharu, and Richard Jenkins, "MMPI Study of Three Types of Delinquents, " Journal of Clinical Psychology, Vol. 23, No. 2, 1967, pp. 156-163. 
22. Volkman, Arthur P., "A Matched-Group Person Comparison of Delinquent and Non-Delinquent Juveniles, "Social Problems, Vo1. 6, No. 3, 1958-59, pp. 238-245.

23. Hathaway, Starke and Elio Monachesi, "The Minnesota Multiphasic Personality Inventory in the Study of Juvenile Delinquents, "American Sociological Review, Vol. 17, 1952, pp. $704-710$.

24. Sheridan, William, "Juveniles Who Commit Non-Criminal Acts: Why Treat in a Correctional System ?" Federal Probation, Vol. 31, No. 1, March 1967, p. 27.

25. Lemert, Edwin M., "The Juvenile Court - 'Quest and Realities', "Task Force Report: Juvenile Delinquency and Youth Crime, Washington, D. C., U. S. Government Printing Office, 1967, pp. 92-93.

26. Goldsmith, Jerome, Harry Krohn, Ruth Ochroch and Norman Kagan, "Changing the Delinquent's Concept of School," American Journal of Orthopsychiatry, Vol. 29, April 1959, p. 249 .

27. Marland, Sidney P., Jr., "Ferment in the Schools, "Children, Vol. 12, No. 2, March-April 1965, p. 63. 
CHAPTER III

\section{METHODOLOGY}

As discussed in chapter one, the focus of this study was to explore, classify and evaluate the subjective experiences of boys released to the community from a state training school. Evidence in the literature indicated practical value in a study of this nature as little seemed to be known about the day-to-day problems of delinquent offenders following institutional release. Portland Public School authorities, as well as the MacLaren School for Boys had also indicated a desire for more descriptive research on post-institutional adjustment, particularly in terms of unmet social, educational and counseling needs.

It was within such a framework that this study was undertaken.

\section{$\underline{\text { Research Design }}$}

During the early weeks of Spring, 1967, the objectives of this projectwere outlined. From the outset, it was decided that this would be an exploratory study emphasizing a close rapport with delinquent youth. Boys released from the MacLaren Institution would be interviewed on a weekly basis to learn of major, minor and critical experiences encountered while on parole. Interviews would be held primarily in person to determine cognitive, connotative, 
attitudinal and behavioral reactions over time. Problems of interpersonal $\dot{r}$ elationships were to be ascertained and related to a number of independent variables such as age, race, socio-economic background and prior delinquent experiences. Analysis of data would be largely descriptive, based upon verbal responses recorded in interview schedules and selected case vignettes.

It was tentatively established that the depth interview technique would be used with the boys to focus attention upon specific experiences and to determine their effects. This type of interview received wide acceptance in the literature and had been applied successfully in a recent study by Allen et al., in which the attitudes of delinquent offenders were explored in seven specific areas (1). Other reliable measures of adjustment were available in Atlantic Street Study eight item and thirty item indices (2), the Pupil Behavior Index (3), and the Minnesota Multiphasic Personality Inventory (4). It was felt that these instruments could be used in formulating items for the interview schedule and provide objective measurement over unknown variables. MMPI scores, available from the MacLaren Institution, were discussed as a control for those cases where deepseated personality disturbances were likely to exaggerate or distort responses in the study population. Institutional, case histories and school records were also suggested to provide necessary background 
information on the boys and to illuminate additional variables of adjustment.

In view of time and resource factors, a ten month study was deemed suitable to meet the research objectives. With the assistance of school and institutional authorities, a population of boys would be formed and contacted during the summer. Relationships would be established, and regular interviews would be carried out during the first two months of school. Two months would then be devoted to the tabulation, coding and analysis of data, followed by two months of evaluating findings and drafting the final report. With minor exceptions, this timetable was followed throughout the study.

\section{Formulating Interview Questions}

Approaching adjustment problems within a population of delinquent boys necessitated an interviewing framework sufficiently broad to encompass the full gamut of the boys' experiences, yet definitive to a point of quantification and statistical analysis. To meet these requirements, a schedule was proposed based upon itemized questions found in the literature and additional items formulated by the research group itself.

During a three week period, a series of open, closed and fixed alternative questions were accumulated. Upon inspection, these encompassed six major topical areas: 1. school, 2. family, 
3. peer group, 4. community, 5. work, and 6, authority. The questions were subsequently judged by the entire research group for appropriateness and clarity of meaning. Approximately eighty questions were retained which were found to be most pertinent to postrelease experiences.

Prior to this time, two members of the research group had contacted the C-CAP Opportunity School, a local community youth center, and had spent several weeks talking with the boys who spent much of their time there. These boys, between the ages of fifteen and eighteen, were from a high delinquency area, and most were high school drop-outs who carried official records of delinquency. The boys were asked to evaluate the proposed questions and to offer any suggestions, changes and criticisms they felt would make the schedule more precise and meaningful.

Five consecutive weeks were devoted to the pre-testing of questions at the opportunity school, and the boys' verbal opinions were used as the basis for revision. One tape-recorded session was made during the final week of pre-testing, and this assisted the research group in understanding better the focus and climate of the interviews. 
Results of the Pre-test

From the experience of interviewing boys at the C-CAP Oppor tunity School, it became evident that closed ended questions did not promote the desired richness of responses nor facilitate a close rapport between interviewer and interviewee. Questions formulated on the basis of scaled intensities of feeling and frequency normally resulted in flippant responses, superficial involvement or in some cases, complete non-involvement. Fixed-alternative "yes" and "no" questions illuminated little more than the information requested, with no further initiative on the part of the boys to clarify their feelings, attitudes and motivations.

Eventually, the test interviewers were forced to abandon specific wordings in the questions and approach the boys in a more generalized fashion. Open-ended questions, such as, "what were some of your experiences with your friends this week, "brought forth greater subjective reaction and encouraged the boys to relate to the interviewers in situational terms. In particular, the boys sensed positive and negative connotations in most areas of their relationships and verbalized feelings on this basis.

It was eventually determined that the schedule would be composed of open-ended questions allowing the boys freedom to respond in terms of "good" and "bad" experiences. Pre-testing experiences 
indicated reliability in such a format and promoted the recording and categorization of verbatim comments free from the interviewers' judgments concerning adjustment. It was also found that clear language, persistent clarification of responses and the maintenance of a warm relationship facilitated the content of the interviews and enhanced their descriptive qualities.

The completed schedule was organized in word outline form, dichotomizing good and bad experiences in the six topical areas of relationships. These were further sub-categorized, in order to specify precise circumstances under which the boys could recall a person, an event or an activity. The word "other" was added as a sub-category to account for any additional personal experiences not foreseen or relatively uncommon in the six areas.

A second section was added to the schedule to record critical incidents. These were operationally defined as any act or experience, of either positive or negative value to the boys, which could result in their being returned to MacLaren. Information in this section specified: a. the nature of the incident, b. circumstances surrounding the incident, c. persons, if any, who were with the boy at the time, d. how the boy felt about the incident and e. the consequences (See Appendix). 


\section{Study Hypotheses}

Once the interview schedule had been completed, the major study hypotheses were formulated. Based upon items in the schedule, as well as other variables to be measured later in the study, were the following nine propositions:

1. No significant difference with respect to the number of positive and negative experiences between Negro and White boys.

2. No significant difference between tho se who remain in school and those who drop out with respect to positive and negative experiences.

3. No significant difference between older and younger boys with respect to negative experiences.

4. No significant difference between the first and second month of the study with respect to the numbers of positive and negative experiences.

5. No significant difference between boys remaining in school and those returned to MacLaren with respect to the number of critical incidents.

6. No significant difference with respect to the number of positive and negative experiences between and within the categories.

7. No significant difference between boys acting alone and those acting in groups with respect to the number of positive and negative experiences.

8. No significant difference between boys dropping out of school and those remaining in school with respect to the number of positive and negative experiences.

9. No significant difference between boys within the top quartile of the paranoid scale of the MMPI and those in 
the lower three-fourths of the scale with respect to the number of critical incidents.

The hypotheses were stated in null form to serve a guiding, rather than definitive purpose. Positive and negative experiences as well as critical incidents were to be related to individual categories in the schedule to determine the general quality of the boys' adjustment. Age, race, educational and time factors were arbitrarily selected on the basis of group consensus, although it was realized that other intervening variables would exist in the study population. Once formulated, the hypotheses were not considered exhaustive or more than indicative for the purposes of exploration.

\section{Selecting the Study Population}

During the last week in May a field visit to MacLaren was made to obtain a sense of the program, to talk with some of the boys personally and to learn of their experiences with reference to the institution.

Juvenile parole officers within the institution were interviewed to establish working relationships during the Fall interviewing period. A request was made for a list of forty boys entering Jefferson, Lincoln and Grant High Schools in September, 1967, who would be willing to serve as participants in the study group.

While it was not known precisely how many boys could be 
recruited according to these criteria, the juvenile parole officers were given some discretion in arriving at a manageable study population. Numbers in excess of forty boys were considered too great to facilitate adequate personal contact, while tho se below twenty were determined to be too few for valid statistical analysis. The selected high schools, all within the same geographic area, provided a broad representation of social, economic and class factors which would have a bearing on both the quality and quantity of experiences encountered. Age was not a determining factor in the selection guidelines, other than to prescribe that the boys all be enrolled in high school following release.

Juvenile parole officers agreed to have the study population formed by late summer and indicated full support for the research project. Social workers and guidance counselors from the three selected high schools had also been contacted during earlier stages of planning and were prepared to assist in the placement and follow-up of any boys who would be participants in the project.

\section{Collecting Background Data}

The first stage of data collection was undertaken at MacLaren School during a three week period in the month of August. At that time, a list of forty-two boys had been submitted by parole officers to the research group. Under the approval of institutional authorities, 
background information on each of these boys was gathered from institutional case records and recorded on standardized forms by alternating teams of two. Attention was given to such factors as age of the boys, racial-ethnic backgrounds, size and composition of families, economic status of parents and history of delinquent crimes. To preserve confidentiality, the names of the boys were transcribed into code and designated only by number, initial of last name, initial of school and initial of parole officers. Addresses and telephone numbers for primary contacts were later to be determined by decoding process based upon a master list of names and corresponding codes.

In addition to the gathering of case history information, MMPI Paranoid and Psychopathic sub-scales were acquired from the psychology staff of the institution. Although these tests were to be utilized later in the study as a check on the frequency of critical incidents in the population, not all of the boys had been tested during their stay at the institution. It was decided, however, that as many tests as were available would be gathered and incorporated into the data for future use.

\section{Limits on the Study Population}

While it had been hoped that initial contacts would be made prior to the boys' entering school, this was not possible in many 
cases. Riot conditions in Portland during the month of August had forced institutional authorities to delay placement of the boys until early September to alleviate the danger of involvement in neighborhood disturbances. Placements were also delayed due to the partial restriction of the school social work program in the Portland Public Schools. This necessitated parole officers assuming full responsibility for registering the boys in school. In many of these situations, boys originally designated to return to the three selected high schools were eventually placed elsewhere.

Some of the boys were dropped from the study population when it was learned that they had left town, joined the military service or had taken on full-time jobs instead of returning to school. Others who had been released in late summer violated parole before school had convened and were returned to the institution in a matter of weeks. These latter cases, however, were not dropped from the study as it was decided they could be interviewed in the institution itself.

\section{Conducting the Interviews}

During the months of September and October, 1967, personal interviews with the boys were undertaken. Training sessions were held concerning the establishment of initial contacts, gaining the boys' support and following through on weekly interviews. 
The interviewers were instructed to use simple language, to follow the check list item s thoroughly and consistently, and to make clear to the boys the confidential nature of the research relationship. While rapport and candor were emphasized to insure factuality of responses, the boys were to be instructed not to expect support from the interviewers if faced with problems requiring adult guidance. In addition, it would be emphasized to the boys that their participation in the project, if not of direct benefit to them, might nevertheless assist other boys in the future. Similar instructions would be given to parents, foster parents and legal guardians in order to gain their full support and cooperation.

Case assignments were drawn on a random basis from two groups to insure that collected data on boys did not pertain to the case load of interviewers having previously collected background information on the same boys. In this fashion, interviews would be conducted blind with reference to background variables, and would prevent the interviewers from being predisposed regarding the boys' experiences.

Initial contacts with the boys posed problems in many instances. A group meeting at the C-CAP Youth Opportunity Center was held to introduce the project to some of the boys who resided in the area but drew a response of less than one-half the number anticipated. In some cases, home telephone numbers were not available, requiring 
a series of trial-and-error home visits until the boys could be seen personally.

In a small number of cases, the boys were prevented from taking part in the study because of suspicion or resistance on the part of parents. Eventually, these cases were dropped from the study due to time limitations in attempting to gain the approval of parents. These cases, when combined with others which had been dropped for reasons previously cited, eventually limited the study population to twenty-three boys. Of these, five were returned to MacLaren for parole violations. Eighteen boys were successfully contacted and followed in the community during the two month study period.

After personal contacts with the boys had been established, telephone interviewing was found to be successful in maintaining weekly reports of experiences. The interviewers also found success in talking with the boys at school or by meeting them in the evenings for a coke or sandwich. As a general rule, the boys were more verbal and relaxed when questioned away from their homes or their schools. Interviews conducted in the homes were always maintained in private as a basic right to the boys and as a means of limiting distractions on the part of family and friends.

Techniques during the interview were primarily tho se of questioning, listening closely to the boys' responses, refocusing on areas 
which were not clear and checking appropriate items on the schedule. Immediately following the interview, detailed descriptions of positive and negative experiences were recorded corresponding to items which had been checked on the schedule. Only specific positive and negative experiences, based upon the boys' personal judgments, were considered in this process. Responses describing general patterns of behavior ("I went to school every day this week") or ongoing relationships ('My girlfriend and I sat down and talked a lot together.") were not recorded. Critical experiences were recorded as thoroughly as possible, specifically with reference to the boys' relationships with authority figures. Code name, time, day and month of interview were also specified to prevent duplication and overlap.

\section{Tabulation and Statistical Analysis}

At the end of October interviewing was terminated. Prior to the breaking of personal contacts, the boys were questioned regarding incomplete or ambiguous data. Interview schedules were then reviewed by the entire research group for accuracy of reporting and to establish clarity of items. Personal experiences which were found to be vague in timing and intensity were either dropped or assigned statistical weights to be tabulated more precisely. All experiences were hand-tabulated on a master sheet, designating total numbers of positive and negative reactions for each boy according to area and 
sub-category of relationship, and according to month of occurrence. The months of September and October were tabulated separately to determine possible trends in the quality, quantity, and distribution of experiences over time.

Statistical analysis of the data was undertaken by the entire research group under the supervision of two members. All members gathered case vignettes to illustrate some of the boys' adjustive experiences and to provide descriptive examples of the statistical findings.

The nine research hypotheses were tested principally by means of the chi square, using one degree of freedom throughout. In all cases the .05 level of significance was chosen to determine whether relationships between experiences and independent variables were empirically valid or due to chance. The $z$-test was used as a comparative check upon the results of chi square.

Other data were analyzed by observation when found to be of insufficient quantity to merit usage of the aforementioned tests. This applied principally to critical incidents, which were reported by the boys less frequently than day-to-day positive and negative experiences.

Upon completion of the statistical computations, the findings were discussed by the entire group. Two members agreed to write the chapter dealing with statistical analysis of the data, while others 
volunteered to work individually on chapters describing the introduction of the study, review of the literature and the research methodology. Upon completion of these chapters, the group met together and contributed ideas which seemed to indicate areas for further study. These ideas and implications were summarized by one member of the research group and are presented in further detail in Chapter Five. 
Chapter Notes

1. Allen, et al., "Use of the Depth Interview in Examining Attitudes of Delinquent Boys: An Exploratory Study, "Portland State College, School of Social Work, Portland, Oregon, 1964. p. 51.

2. Seattle Atlantic Street Center, "Effectiveness of social work with acting-out youth: fifth year progress report," September 1966 August 1967.

3. Vinter, et al. , Pupil Behavior Inventory, A Manual for Administration and Scoring, Ann Arbor: Campus Publishers Co., 1966.

4. Hathaway, Starke, and Elio Monachesi, "The Minnesota Multiphasic Personality Inventory in the Study of Juvenile Delinquents," American Sociological Review, Vol. 17, 1952, pp. 704-710. 
CHAPTER IV

\section{FINDINGS}

\section{Consideration of Major Variables}

This study was concerned with the numbers and areas in which positive and negative experiences occurred in the boys' lives, as related to their general adjustment and their success in the community. In this chapter the findings of the tested hypotheses are presented. The hypotheses which yielded significant test results are presented first. Significant results were tho se that produced chi square values beyond a 5\% level of significance. The second part of the chapter deals with the hypotheses that did not. Statistical observations that could be most meaningfully presented in descriptive form are presented last.

The boys studied designated which experiences they considered favorable or unfavorable, sometimes using the terms positive and negative to denote the type of atmosphere or affect they experienced during the situation, and sometimes using the terms to indicate whether a positive or negative outcome resulted.

By comparing the six different categories in the boys' lives which were designated on the check list, indices of where large numbers of significantly different experiences occurred could be isolated. 
Even though it was suspected in some cases what direction the alternative hypothesis might take, the two-tailed test was used throughout this study to identify relationships because of its exploratory nature.

In each case, if the chi square was significant, a $z$-test was administered to the data to check the observed impressions of direction. The critical value was 3.841 in all cases.

The first problem was to fix the locus of positive and negative relationships and to estimate the extent and significance of differences. By comparing the boys' experiences in various paired settings a picture of relative satisfactions and dissatisfactions, constructive and destructive forces, and factors in the boys' choices of relationships were obtained.

The hypotheses outlined in the previous chapter were reformulated to test the variables in the following manner:

Ho: For the months of September and October taken separately there was no difference in the number of positive and negative experiences between the compared categories of relationships.

The largest contrast in positive and negative experiences reported in September occurred between Family and Peers. The boys reported while among their peers an extremely large number of favorable experiences, in striking contrast to the experiences that occurred with their families. In the family area of their lives, while 
Table 1

Categories in Which the Number of Positive and Negative Experiences Reported Were Significantly Different

(Arranged by size of difference in each month)

\section{$\underline{\text { September }}$}

Loci of Experiences Compared

$x^{2} \cdot 05$

Family/Peers

44.550

Authority/Peers

20.204

School/Peers

17.987

Family/Community

13.501

Community/Peers

8.364

Family/School

6.982

Family/Work

6.680

\section{October}

Loci of Experiences Compared

School/Peers

50.543

Family/Peers

50.320

Authority/Peers

23.543

School/Community

21.768

Family/Community

21.172

Work/Peers

12.884

Authority/Community

8.759

Work/Community

4.336

1. Categories with greater number of negative experiences given first.

2. Categories with greater number of positive experiences given second.

3. One degree of freedom throughout.

4. Yates correction for continuity. 
some positive experiences did occur, the boys as a whole reported a preponderance of negative experiences.

During October the contrast between School and Peers yielded the highest significant test statistic. The boys had had a few positive experiences at school during September, but by October the positive experiences dropped by one half and the negative experiences remained as high as they had in September. This made the category appear more negative. Since the number of negative experiences in the Family category remained constant throughout the two months, School moved to the most negative position in October.

The four most negative comparisons that occurred in both September and October were: Family/Peers, Authority/Peers, School/Peers, and Family/Community. Evaluating a category as a single unit, the most positive groups, or the ones in which the boys reported the most positive experiences, were Peers and Community.

The highest proportion of negative experiences occurred in the Family, with Authority and School ranked as the next highest negative groups during the entire study. The highly negative categories of Community/Peers, Family/School, and Family/Work occurred only in September. The categories of School/Community, Work/Peers, Authority/Community, and Work/Community occurred as significant only in October. These may indicate shifts in the boys' adjustment patterns. 
Some of the categories revealed no significant differences and the null hypothesis could not be rejected. The boys in the sample did not report a significant difference in the number of positive and negative experiences in any of the comparisons in the following table:

Table 2

Categories in Which the Number of Positive and Negative Experiences Reported Were Not Significantly Different

(Arranged by size of difference for both months)

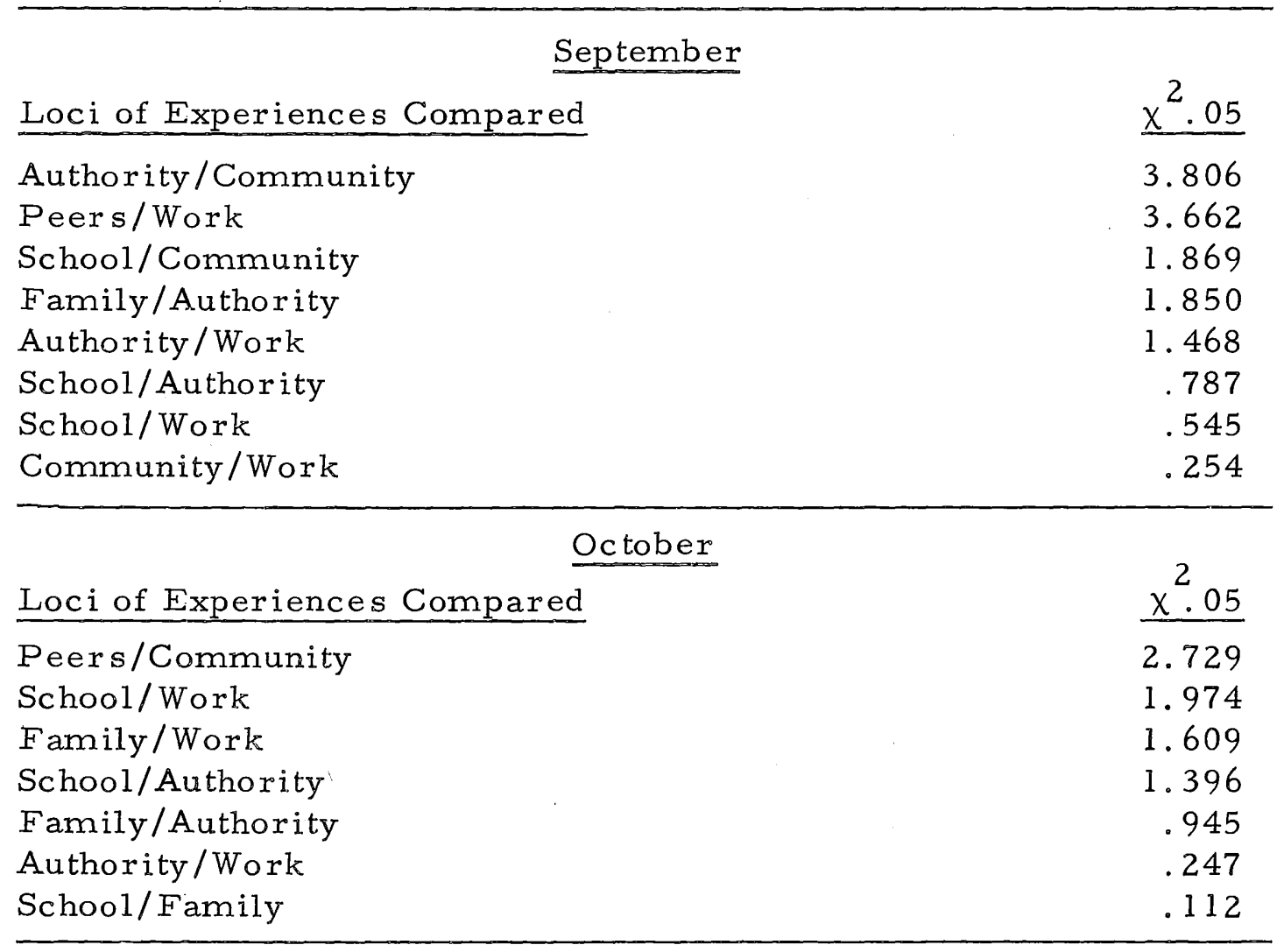

1. Categories with greater number of negative experiences given first.

2. Categories with greater number of positive experiences given second.

3. One degree of freedom throughout.

4. Yates correction for continuity. 


\section{Consideration of Internal Variables}

Additional hypotheses were set up to see whether certain plausible variables might have affected the results of our principal hypotheses. The additional hypotheses tested the changes in the number of responses in each category with respect to a period of time, race, and age.

Differences by Time

Ho: The number of experiences which the interviewees considered negative were the same for September and October in each category.

\section{Table 3}

Categories in Which the Number of Positive and Negative Experiences Reported Were Not Significant, Comparing September and October

(Categories in order of largest test result)

\section{September and October}

Loci of Experiences

School

3.468

Community

2.937

Peers

1.350

Family

.485

Work

Authority

1. One degree of freedom throughout.

2. Yates correction for continuity. 
In this study time did not seem to be a significant factor as related to the number of positive and negative experiences the boys reported during September and October. In September and October the number of positive experiences changed little, but there were a few more negative experiences in October.

Differences by Race

Ho: The number of experiences which the interviewees considered negative were the same for Negroes and Whites during September and October in each category.

\section{Table 4}

Categories in Which the Number of Positive and Negative Experiences Reported Were Not Significant, Comparing Negro and White Boys for September and October

(Categories in order of largest test result)

September and October

Loci of Experiences

$x^{2} .05$

Authority

3.584

School

1.904

Community

.611

Family

Peers

.048

Work

By inspection

1. One degree of freedom throughout.

2. Yates correction for continuity.

The table shows no significant difference between the races, leading to the acceptance of the null hypothesis. Although the result 
in the area of Authority was not significant at this level, it should be noted that it was nearly significant since Negroes reported more negative experiences with Authority than did Whites.

Differences by Age

Ho: The number of experiences which the interviewees considered negative were the same for the younger and older boys during September and October in each category.

Table 5

Categories in Which the Number of Positive and Negative Experiences Reported Were Significant and Not Significant, Comparing Older and Younger Boys in the Two-Month Period

(Categories in order of largest test results)

$\underline{\text { September and October }}$

Loci of Experiences

2

School

$\underline{x^{2} .05}$

Community

5.260

Authority

3.610

Peers

2.632

Work

2. 116

Family

.489

.266

1. One degree of freedom throughout.

2. Yates correction for continuity.

The boys in this study ranged in age from thirteen through

seventeen years. Since half of the boys were seventeen, they were designated as the older group. The older boys had a higher number of negative experiences in the category of school than did the younger 
boys. It should be noted that the majority of seventeen-year-olds in the sample were older than their classmates and behind one or two years in school. Older boys did have a significantly greater number of negative experiences in School than did the younger boys. In the other categories there were no significant difference.

\section{Consideration of Observed Data Within Each Category}

The material within each category lent itself to analysis by observation and revealed certain contrasts and comparisons between the individual items in each category. Each of the six categories is treated in the following paragraphs.

School adjustment was reported under five subdivisions. The boys reported the highest number of experiences with teachers, and these were split nearly equally between being positive and negative.

The boys reported a preponderance of positive experiences with principals and with counselors, although the number of the se experiences reported were far smaller than with teachers or with vice principals.

A high proportion of experiences reported with fellow students were considered negative by the boys. In the two month period the boys reported thirteen negative and two positive experiences.

There were a total of sixty-three positive experiences reported in the category of School and seventy-seven negative experiences. 
One example of a positive experience was a boy"s managing to avoid trouble at school by staying out of the way of the vice principal. An example of a negative experience was a teacher's continually referring to a boy in class as being released from MacLaren.

It was in the Family category that the boys reported the highest number of negative experiences. Ninety-three negative experiences occurred with the father, and a high but equal number of negative and positive experiences were reported with mothers.

The boys who had substitute parents, including foster parents and step-parents, reported approximately an equal number of positive and negative experiences with the se parents.

More negative experiences than positive experiences were reported with brothers, and no large number of experiences of either positive or negative significance were reported with sisters.

An example of a positive experience in this area was a boy who reported that his family did not have any fights at all one day and sat around telling jokes and stories. An example of a negative exper ience was reported by a boy whose parents were so suspicious of him after his release from MacLaren that they placed confining restrictions on him and had a major family battle whenever he could not account for his time.

In Peer relationships the boys reported the largest number of positive experiences: one-hundred-seventy-seven. This number was 
twice as large as the number of positive experiences in the second ranked category-Community. In September there were twice as many positive as negative experiences reported with close male friends, and in October there were five times as many positive as negative. The total number of negative experiences in this category for the two month period was thirty-two. It was clear that the boys saw the peer group as their most positive reference point.

Mixed groups did not seem to play a significantly large part in the boys' experiences. In September there were only two experiences reported in mixed groups; by October, mixed group exper iences had increased to ten.

One half of the boys in the study reported a large number of positive experiences with a steady girl friend while the other half of the group did not report contact with girl friends.

An example of a favorable experience in this category was reported by a boy who, in the company of friends, stopped the car of a boy they did not like and beat him up. An example of a negative experience was reported by a boy who was tricked into taking LSD by one of his friends and became completely incoherent for thirtysix hours. Often the boys mentioned negative experiences with peers as being minor experiences, such as their friends' not picking them up on time. These boys seemed to be very sensitive to the actions of their close male friends. 
In the area of Community relationships, the boys reported eighty positive and thirty-three negative experiences. None of these was with the family's welfare caseworker and only one was with a medical resource, and this experience was negative.

During September there was a large number of positive experiences reported in connection with church, and in October the number of positive experiences remained the same, but the number of negative experiences increased to make the number approximately equal. One negative experience was reported by a boy who discovered that his girl friend had been warned by the minister of their church that the boy was a "potential murderer" and that she was risking her life to continue dating him.

The boys reported positive experiences with Community Action programs in all but one case. The negative experience occurred when the boy dropped a cue stick while playing pool at a community center and was asked to leave. In September the boys reported a large number of negative experiences with neighbors, but in October they reported a large number of positive experiences and a small number of negative experiences.

One-fifth of the boys in this study reported many positive experiences with drugs in September and October, and drug experiences were on the increase in October among this same portion of the sample. 
An example of a positive experience reported in the Community category was a boy's regularly attending a community center to play basketball. An example of a negative experience was reported by a boy who was not allowed to associate with any of the boys in his neighborhood because their parents thought he was a bad influence on their sons.

The boys in the sample reported the smallest number of experiences in the Work category. Only twenty-one positive and sixteen negative experiences were reported, partly because only one-half of the boys were working at one time or another during the study.

The largest number of positive experiences werewith employers, and there were no experiences reported with co-workers. In September, there were an equal number of positive and negative experiences with respect to interviews to obtain work, but in October there were twice as many negative as positive interviewing experiences reported.

An example of a positive experience in this category was reported by a boy who felt that his employer provided encouragement for him to remain in school. Another boy was encouraged by his parole officer acting as a job reference. An example of a negative experience was reported by a boy who was so frightened of new situations that he could not bring himself to go through with any work interviews that he had scheduled. He was also embarrassed because the only two adults he knew who could serve as job references were 
his parole officer and the family's welfare caseworker.

In authority relationships the number of experiences reported were thirty-four positive and forty-one negative. The boys reported twice as many positive as negative experiences with parole officers. Experiences commonly were reported as positive if the contact did not result in the boy's being returned to MacLaren.

The boys reported twenty-two negative experiences and one positive experience with policemen in this two month period. A positive experience was reported by a boy who went to visit a detective in his local precinct at the police station. The detective had previously shown interest in the boy when he had been brought into the station. The boy thought that he had been treated fairly, and saw the officer as an adult friend.

\section{Consideration of Supportive Data}

\section{The Consideration of Critical Incidents}

The consideration of critical incidents was an attempt to get some index of the magnitude of the boys' experiences. A critical incident was any experience that might result in the boy's being returned to MacLaren. The boys decided if the experience was a critical incident or not. This part of the study gave some indication of the nature of the boys' critical incidents as well as where they occurred. 
Table 6

Number of Critical Incidents Reported in September and Oc tober

\begin{tabular}{lcc}
\hline Categories & Positive & Negative \\
\hline School & 0 & 3 \\
Family & 1 & 3 \\
Peers & 10 & 3 \\
Community & 5 & 2 \\
Work & 0 & 0 \\
Authority & 0 & 9 \\
\hline
\end{tabular}

There were approximately an equal number of positive and negative critical incidents reported. All of the categories except Work, Authority, and School contained both positive and negative critical incidents.

The largest number of positive critical incidents occurred among. Peers, and the largest number of negative critical incidents occurred with Authority. The polarity between these two groups is clear as indicated in Table 6.

An example of a positive critical incident was reported by a boy who was taken to juvenile court for committing an offense. While there, he received support from his parents who were able to communicate effectively with him and he was released to their custody instead of returning to MacLaren.

An example of a negative critical incident was reported by a 
boy who was not getting along with his foster father who said he was returned to MacLaren because the foster father falsely accused him of driving the family car and made this known to the parole officer. The objective facts in this situation were not important to the study, but $r$ ather the manner in which the boy perceived the experience.

Differences in Verbal Responses of Returnees and Non-Returnees

All of the critical and non-critical responses of the boys were tabulated and revealed the following information. Of the twenty-three boys in the sample, there were five returned, and they were returned in September. The mean number of responses per boy for September which included returnees and non-returnees was 16.95; in October the average excluding the returnees was 19.65. With the returnees removed from the September count the average response per boy was 18.12. Therefore, returnees did make fewer responses than nonreturnees. Inspection revealed that the average would not have been significantly different per. month if tested. It was found that this factor was unrelated to the boys' adjustment outside MacLaren School for Boys.

Consideration of Two Scales of the MMPI

Consideration was given to the MMPI scores in an attempt to account for the boys' involvement or lack of it in the study and 
their successful adjustment in the community. It was speculated that those boys with normal scores would adjust better than those with high scores.

\section{Table 7}

Frequency of Reported Scores in the MMPI, the Number Four and Six Scales, the Psychopathic Deviate (PD) and Paranoid (PA)

\begin{tabular}{rccc}
\hline & PD & & PA \\
Score & Frequency & Score & Frequency \\
\hline $0-17$ & 0 & $7-10$ & 3 \\
$18-22$ & 1 & $11-14$ & 2 \\
$23-26$ & 2 & $15-19$ & 3 \\
$27-31$ & 5 & $20-$ & 4 \\
$32-$ & 4 & & \\
\hline
\end{tabular}

1. For purposes of evaluation, the Mayo Clinic Automated MMPI program was used. (2)

The PD scale showed that most of the boys fell in the Moderate and Marked areas. These areas were equated to the following descriptive characteristics: rebellious, nonconformist, unreliable, shallow feelings and loyalties, and poor family and social relationships.

The PA scores were randomly distributed among the four PA classifications. However, half of the group in this case received scores in the Moderate and Marked areas of the scale. In 
terms of interpretation, the following descriptions were applicable to the upper half of the sample of boys: resentful of others, touchy, over-responsive to opinions of others, suspicious perhaps to the point of false beliefs.

These high scores on both scales by inspection were not found to be associated with any of the following variables: cooperation in the study, number of experiences reported, severity of offenses, differences between returnees and non-returnees, differences. between Negro and White interviewees.

\section{Consideration by Sex of the Interviewer}

Consideration was also given to the possibility that interviewing was biased as a result of the sex of the interviewers. It was felt that this factor might affect the number of responses and the nature of responses of the boys in the study. Therefore, the number of responses per month were tabulated for men and women interviewers.

In September, male interviewers elicited 17.91 responses per boy. In October the number of responses increased to 21.44 . The female interviewers in September obtained 15.88 responses per boy, and in October, the number increased to 17.63 . The total mean response for both sexes together for September was 16.95 and for October was 19.65. Inspection indicated that the male interviewers obtained a few more responses per boy than did the female 
interviewers, but not enough to make the difference statistically signific ant.

In this chapter, for the most part, comments have been restricted to the major aims of the study. Tables have been presented for those interested in exploring in greater detail the considerable number of interrelationships as related to special areas of interest.

It has been left for the final chapter to explore the larger picture and its implications. 
Chapter Notes

1. Mendenhall, William, Introduction to Probability and Statistics, Belmont, California, Wadsworth Fublishing Company, Inc. , 1967, p. 267, Table 3 .

2. Pearson, John S., and Wendell M. Swenson, A User's Guide to the Mayo Clinic Automated M.M.P.I. Program, New York, The Psychological Corporation, 1967, Table 2, pp. 32-33. 


\section{CHAPTER V}

\section{CONCLUSIONS}

Most of the boys in this study were from the East side of Portland, but represented a variety of social and economic backgrounds. While some of the boys resided in identified war-onpoverty areas, others lived in middle class neighborhoods as well. Major Findings and Their Implications for Practice

This study found that MacLaren School boys have a difficult time adjusting to the community following release, and that they experience major problems in their dealings with families, schools, and representatives of authority. This raises the question, "How effective a job is being done to reintegrate these delinquent boys into the community?" Most of the boys interviewed expressed a desire to become responsible members of the community, but found themselves unable to achieve this goal because society made it so difficult for them. The following pages provide further explanation with respect to this problem.

Much evidence from this study pointed to the fact that little or no work was done with the boys' families before, during, or after institutionalization. As explained in the previous chapter, the boys reported the largest number of negative experiences with their 
families and yet, during times of crises, they were the only ones who received counseling. Bitter comments were frequently expressed by boys who felt they were singled out, time and again, as the perpetrators of family arguments. They likewise felt that they were being compelled to endure hardships beyond their control, particularly when their opinions and feelings were overridden by those of adults.

Circumstances of this nature would seem to imply the need for increased family treatment on the behalf of the youthful offender. Generally, treatment facilities for children in the Portland area refuse to handle individual cases without the cooperation of the entire family. Perhps this same approach, discarding the notion of the "problem child" and taking into consideration the problems within the family unit, could be applied to the field of juvenile corrections as well.

One alternative might be to involve the parents in the program of a boy while he is institutionalized. For example, some of the boys' families have been asked to live for a brief period of time within the structure of other institutional settings in order to understand treatment goals and objectives. Another of several possibilities would be to change the function of the parole officer to include weekly counseling sessions with the family in the community during the boy's incarceration. Whatever the alternative, however, it 
seems imperative that family treatment should be acted upon quickly as a much-needed resource for diver sified and complete juvenile corrections services.

Another of the major areas of difficulty was the boys' re-entry into public school. Problems in this area were reported by the boys as involving their relationships with teachers and fellow students.

It was clear that not enough was known about the boys, both collectively and individually, to enable teachers to handle the variety of problems they represent. In terms of academic requirements, most of the boys felt that they were not able to keep up in the highly structured curriculum demands of their schools. A suggested alternative to this problem is to lengthen the time it takes to complete credits. Another is to expand the use of night classes. Most of the boys wanted to keep up with their schooling, but could not anticipate doing so within the existing framework.

Problems with fellow students seemed, in most cases, to stem from feelings of "being on the outside" as the result of institutional training. It was also apparent that organized efforts were lacking to make the boys feel welcome, at least in part, in some of the schools' activities. Feelings of ostracism ran high among reported experiences. The boys were often trying to adjust to what appeared to them an almost impossible situation.

The area of Authority was the third category of interpersonal 
relationships which the boys found difficult to deal with effectively. It was clearly demonstrated that the boys saw the police as consistently "bad" people to have contact with. Feelings of suspicion and distrust marked all contacts with police, regardless of the consequences. In short, the data revealed that no matter what a policeman did, the boys interpreted it as a negative experience. The gulf in meaningful communication between these two groups is so great, only an extreme effort will bridge this area.

Another important finding was how differently the boys saw the world compared with societal expectations. It was quite apparent that their views of what was favorable and what was unfavorable were often quite different from the views of those with whom they were dealing, with the exception of their close male friends. A zealous effort to be able to see things as they do is perhaps the first step to learning to work with them on a common basis. Possibly an effort should be made to get at their unrealistic, or divergent, attitudes and perceptions, and try to change their perspectives. At best, the boys think they are adjusting to a bad, if not impossible situation. The boys' adjustments are affected by their perception of the actions of the family, school, peers and police.

Some of the boys in the study were reinstitutionalized within a 
few weeks. This study questions whether this allowed sufficient time for them to make an adjustment. Those returnees who were inter viewed felt society "put the screws" to them before they really had a chance. Is society too eager to send them back? When an offense has been committed, possibly the boys could be worked with more intensively at that point. The factors involved in this situation need further attention. It is clear there is no one consistent adult the boys can turn to for support and help.

The boys' greatest satisfaction came from their peer group. They consistently reported close and satisfying experiences with their male friends and girl friends. With an environment that was generally negative in other areas, there was little doubt that the peer group, for these boys, served to satisfy the needs of affection, security, and identification they had not found in their families. Many times, the boys demonstrated their sensitivity to the actions of their close male friends. This behavior is in contrast to the impression society holds about their insensitivity. It became clear that the boy's satisfaction was related directly to the se positive experiences with friends.

\section{Further Findings}

The boys experienced a great deal of difficulty in the home setting. Frequently mentioned examples of a negative experience 
were ongoing arguments with the mother or father. The arguments, furthermore, usually centered around the futile efforts by the parents to curtail the boy's activities.

At school, the boys experienced considerable difficulty with teachers, usually associated with their being behind in school work. In addition, life outside the school setting was not conducive to good school performance.

The boys' major problems with fellow students centered around small fights and exchanges of bitter words. These fights were usually about girl friends, the boys' aggressive behavior, or personality clashes.

The boys' negative experiences with police ranged from just seeing a policeman patrolling their neighborhood, to the boys' apprehension for committing a crime. All areas of relationships showed a range, a subject in itself, for further study.

\section{Criticisms and Implications}

A random sample instead of a cohort sample is recommended for future studies. Because the sample for this study was not random, issues may have been raised that are not typical.

More information to determine the extent and intensity of delinquent boys' experiences is suggested as another area for future study. 
In any future study, greater effort should be put into the preparation of the boys and their families in order to involve them more successfully in the projects. An incentive of money or refreshments has been suggested to encourage participation in interviews.

One pre-test indicated that the boys responded most candidly to open ended questions, and the check list was generally satisfactory to record verbatim responses. The major criticism of the check list was in the areas of family and school. A greater differentiation among persons and types of experiences is needed within these two categories.

A study of boys returning to the community in the middle of the school year would probably reveal a different set of adjustment problems, particularly in the school setting.

Some attention should be paid to what is meant by satisfactory adjustment, as it. was found that many of the boys designated as having adjusted were still commiting acts for which, if caught, could have returned them to the MacLaren School for Boys. What is it, then, in the nature of general behavior, which causes one boy to be considered "adjusted" and another not, even though they are doing the same act?

Finally, it might be asked, what is it in the attitude of families, schools, and authorities which places these boys in opposition to the se social institutions? The answer cannot be directed toward the 
boys alone, for they perform satisfactorily in their own groups, and their acts in these groups are not all delinquent.

As so often happens in research, many more questions have been raised than have been answered, and much more has been accomplished than reported. Perhaps the main contribution of this study has been to call to the attention of researchers and practitioners the rich and meaningful private experiences, however small, of young people in trouble. 


\section{SELECTED BIBLIOGRAPHY}

\section{General Background}

1. Allen, Alice, et al., "Use of Depth Interview in Examining Attitudes of Delinquent Boys: An Exploratory Study,"Unpublished Thesis, School of Social Work, Portland State College, 1964.

2. Barron, Milton L., The Juvenile in Delinquent Society, New York, Alfred A. Knopf, 1954.

3. Beck, Bertram M., "Innovations in Combating Juvenile Delinquency," Children, Vol. 12, No. 2, March-April, 1965, pp. 6974 .

4. Berleman, William and Thomas Steinburn, "The Execution and Evaluation of a Delinquency Prevention Program, "Social Problems, Vol. 14, No. 4, 1967, pp. 413-423.

5. Cohen, Albert and James Short, "Research in Delinquent SubCultures," Journal of Social Issues, Vol. 14, No. 3, 1958.

6. Ellington, John R., "Youth Authority Plan and Its Development in California, " California Youth Authority Quarterly, Vol. 20, No. 3, Fall, 1967, pp. 17-32.

7. Elliott, Mabel, Ph.D., "Trends in Theories Regarding Juvenile Delinquency and Their Implications for Treatment Programs," Federal Probation, Vol. 31, No. 3, September, 1967, pp. 3-11.

8. Empey, La Mar T., "Delinquency Theory and Recent Research," Journal of Research in Crime and Delinquency, Vol. 4, No. 1, January, 1967, pp. 28-42.

9. England, Ralph, Jr., "A Theory of Middle-Class Delinquency," Journal of Criminal Law, Criminology and Police Science, Vol. 50, No. 6, March-April, 1960, pp. 535-540.

10. Erickson, Maynard and Lamar Empey, "Court Records, Undetected Delinquency, and Decision Making, " Journal of Criminal Law, Criminology, and Police Science, Vol. 54, No. 4, December, 1963. pp. 456-569. 
11. Erikson, Erik, Childhood and Society, New York, W. W. Norton and Co., 1950.

12. Gold, Martin, "Undetected Delinquent Behavior, "Journal of Research in Crime and Delinquency, Vol. 3, No. 1, January, 1966, pp. 27-46.

13. Goldsmith, Jerome, Krohn, Harry, Ochrach, Ruth and Kagan, Norman. "Changing the Delinquent's Concept of School," American Journal of Orthopsychiatry, Vol. 29, April 1959, pp. 249-265.

14. Hathaway, Starke, and Monachesi, Elio, "The Minnesota Multiphasic Personality Inventory in the Study of Juvenile Delinquents, "American Sociological Review, Vol. 17, 1952, pp. 704710 .

15. Hirschi, Travis, and Selvin, Hanon, Delinquency Research: An Appraisal of Analytic Methods, New York, The Free Press, 1967 .

16. Holleman, James, McCune, John and Ray, Thomas. "Manifest Anxiety and the Postinstitutional Adjustment of Young Offenders, " Journal of Research in Crime and Delinquency, Vol. 3, No. 1,1966 .

17. Lemert, Edwin M., "The Juvenile Court--Quest and Realities," Task Force Report: Juvenile Delinquency and Youth Crime, Washington, D. C., U. S. Government Printing Office, 1967, pp. $91-106$.

18. Marland, Sidney P., Jr., "Ferment in the Schools, "Children, Vol. 12, No. 2, March-April, 1965, pp. 62-68.

19. Martin, John M., "The 'Sociological Imagination' Applied to Juvenile Court Policy-Making, "American Journal of Or thopsychiatry, Vol. 37, No. 2, 1967, pp. 362-363.

20. Nye, F. Ivan, Short, James, and Olson, Virgil, "Socioeconomic Status and Delinquent Behavior, "The American Journal of Sociology, Vol. 63, No. 4, January, 1958, pp. 381-389.

21. Reckless, Walter C., Dinitz, Simon, and Murray, Ellen. "Self-Concept as an Insulator Against Delinquency," American Sociological Review, Vol. 21, No. 6, December, $195 \overline{76, \text { pp. 744- }}$ 746. 
22. Rowley, Vinton and Stone, F. Beth, "MMPI Differences between Emotionally Disturbed and Delinquent Adolescents, "Journal of Clinical Psychology, Vol. 18, No. 4, 1962. pp. $481-484$.

23. Schwitzgebel, Ralph, Streetcorner Research, Cambridge, Massachusetts, Harvard University Press, 1964.

24. Seattle Atlantic Street Center, "Effectiveness of Social Work with Acting-Out Youth: Fifth Year Progress Report, "September 1966 - August 1967.

25. Sheridan, William, "Juveniles Who Commit Noncriminal Acts: Why Treat in a Correctional System ?" Federal Probation, Vol. 31, No. 1, March, 1967, pp. 26-30.

26. Shinohara, Atsuharu, and Jenkins, Richard, "MMPI Study of Three Types of Delinquents, " Journal of Clinical Psychology, Vol. 23, No. 2, 1967, pp. 156-163.

27. Tangri, Sandra S., Schwartz, Michael, "Delinquency Research and the Self-Concept Variable, "Journal of Criminal Law, Criminology, and Police Science, Vol. 58, No. 2, 1967 , pp. 182-190.

28. Vinter, et al., Pupil Behavior Inventory, A Manual for Administration and Scoring, Ann Arbor: Campus Publishers Co., 1966.

29. Volkman, Arthur P. "A Matched-Group Person Comparison of Delinquent and Non-Delinquent Juveniles, "Social Problems, Vol. 6, No. 3, 1958-59, pp. 238-245.

30. Wattenberg, William W., Social Deviancy Among Youth, Chicago, National Society for the Study of Education, 1966.

\section{Statistics}

1. Mendenhall, William, Introduction to Probability and Statistics, Belmont, California, Wadsworth Publishing Company, Inc., 1967.

2. Pearson, John S., and Wendell M. Swenson, A User's Guide to the Mayo Clinic Automated M.M.P.I. Program, New York, The Psychological Corporation, 1967. 
APPENDIX 
APPENDIX

INTER VIEW SCHEDULE

Code:

Week of:

Interviewer:

Type of Interview:

\begin{tabular}{|c|c|c|}
\hline CATEGORY & $\begin{array}{l}\text { WHAT GOOD } \\
\text { HAPPENED }\end{array}$ & $\begin{array}{l}\text { WHAT BAD } \\
\text { HAPPENED }\end{array}$ \\
\hline \multicolumn{3}{|l|}{ 1. $\mathrm{SCHOOL}$} \\
\hline \multicolumn{3}{|l|}{ Teachers } \\
\hline \multicolumn{3}{|l|}{$\begin{array}{l}\text { Vice } \\
\text { Principal }\end{array}$} \\
\hline \multicolumn{3}{|l|}{ Principal } \\
\hline \multicolumn{3}{|l|}{ Counselor } \\
\hline \multicolumn{3}{|l|}{ Students } \\
\hline \multicolumn{3}{|l|}{ Others } \\
\hline \multicolumn{3}{|l|}{ 2. FAMILY } \\
\hline \multicolumn{3}{|l|}{ Father } \\
\hline \multicolumn{3}{|l|}{ Mother } \\
\hline \multicolumn{3}{|l|}{$\begin{array}{c}\text { Substitute } \\
\text { Parents }\end{array}$} \\
\hline Parents & & \\
\hline \multicolumn{3}{|l|}{ Brother(s) } \\
\hline \multicolumn{3}{|l|}{ Sister $(s)$} \\
\hline \multicolumn{3}{|l|}{ Others } \\
\hline \multicolumn{3}{|l|}{ 3. PEER GROUP } \\
\hline \multirow{2}{*}{\multicolumn{3}{|c|}{$\begin{array}{c}\text { Close Male } \\
\text { Friends }\end{array}$}} \\
\hline & & \\
\hline \multicolumn{3}{|l|}{ Mixed Group } \\
\hline Girl Friend & & \\
\hline
\end{tabular}




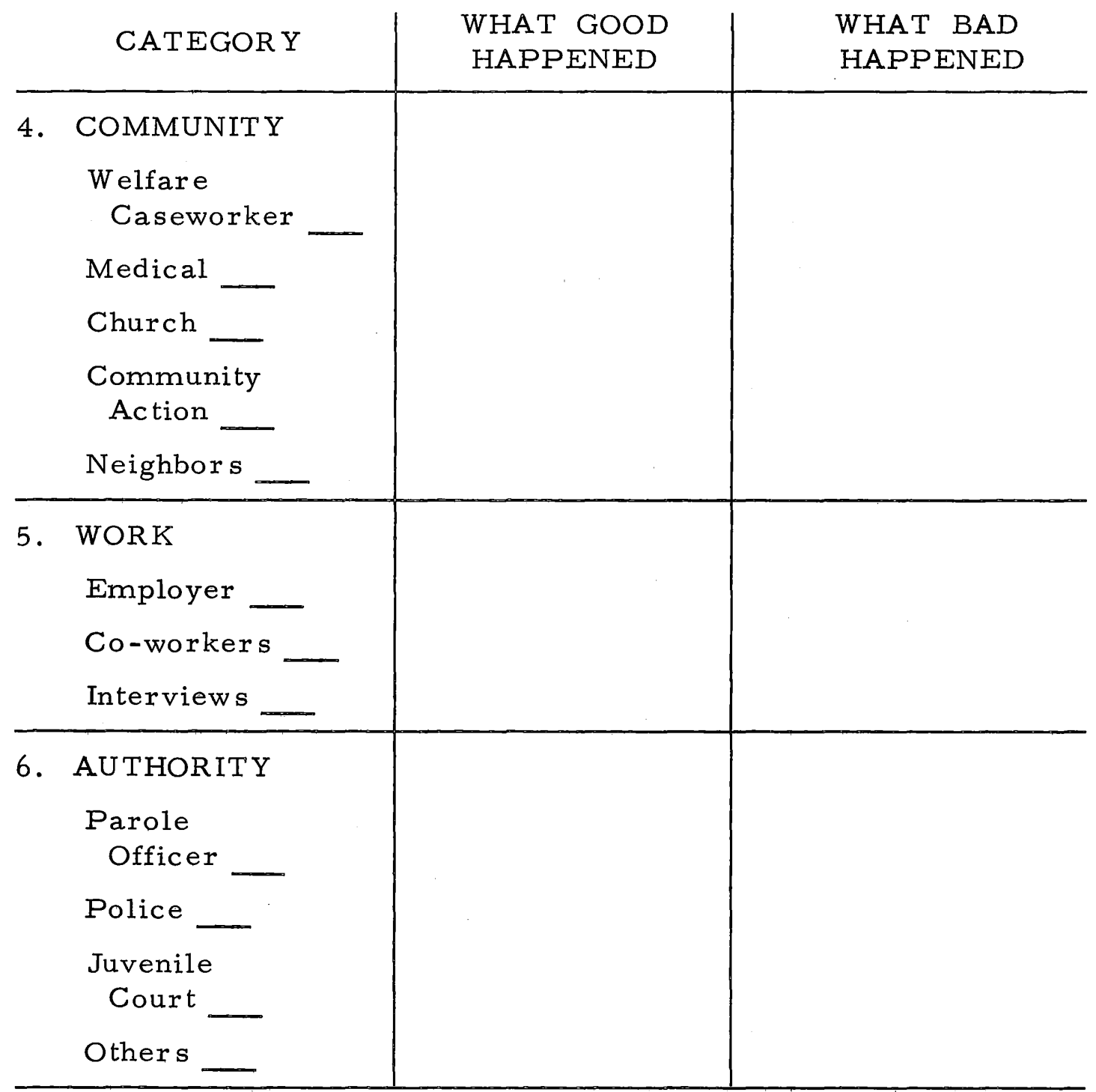

CRITICAL INCIDENT

1. Factors surrounding the incident.

2. People who were with him.

3. How he felt about it.

4. Consequences. 